\title{
Business Leksikon
}

\begin{abstract}
This review article deals with a specialised dictionary recently introduced to the Danish market. It covers traditional business subjects and is designed for semi-experts and laypeople. Through Danish definitions and English, French and German equivalents, it aims at fulfilling the functions text reception, text production, translation and knowledge acquisition. The main aspects addressed are presentation of lemmata, structure and presentation of definitions, grammatical information and diasystematic labelling and their relation to the functions of the dictionary. The general impression is that the lexicographic work leaves much to be desired, and that the dictionary can be recommended for text reception and knowledge acquisition, whereas it cannot be recommended for text production and translation.
\end{abstract}

\section{Indledning}

I november 2001 udkom endnu en ny fagordbog på det danske marked. Det drejer sig om Business Leksikon. Århus: BK SERVICE 2001, pris kr. 576 ekskl. moms. Ordbogen er en videreudvikling af Dansk Eksportleksikon, der blev udgivet af det samme firma i 1993. Ideen til Business Leksikon er opstået i samarbejde med kunder og samarbejdspartnere, der på forskellig måde, har givet udtryk for, at der var brug for et nyt opslagsværk til dækning af deres behov. I lighed med den første udgave, er Business Leksikon udarbejdet af et forfatterteam, der i denne omgang består af Niels Johansen, Bozhidar Kezunovich, Lars Kiertzner, Jens Peder Lynderup, Carl-Johan Nielsen og Kurt Pedersen, samt tre oversættere, nemlig Liselotte Fuglsang Andersen (fransk), Birthe Mousten (engelsk) og Joachim Schote (tysk). Som resultat af det udvidede samarbejde og forfatterteamets mange kernekompetencer i forhold til Dansk Eksportleksikon, har man valgt at ændre ordbogens titel til det engelsk/danske Business Leksikon.

\footnotetext{
* Sandro Nielsen

Engelsk Institut

Handelshøjskolen i Århus

Fuglesangs Allé 4

DK-8210 Arhus V

sn@asb.dk
} 
Business Leksikon er en flerfagsordbog, der primært behandler udtryk og begreber fra fagområderne udenrigshandel, import, eksport, jura, generel $\varnothing$ konomi, nationaløkonomi, regnskabsvæsen, international transport og reklame (se Nielsen 1990, 132-135). Samtidig kan den betegnes som en flersproget fagordbog, idet den indeholder oversættelser til engelsk, fransk og tysk af de udvalgte fagudtryk. I det følgende vil udvalgte leksikografiske og faglige aspekter blive diskuteret.

\section{Ordbogens brugergruppe og funktioner}

Når man skal udarbejde og vurdere en ordbog, er det mest hensigtsmæssigt at tage udgangspunkt $i$ ordbogens intenderede brugergruppe og ordbogens genuine funktion(er). Business Leksikons brugergruppe er delt i tre undergrupper, nemlig 1) medarbejdere i virksomheder og organisationer, som i forbindelse med deres planlæggende eller udførende arbejde, har et informationsbehov, som kan dækkes af ordbogen, 2) studerende og elever på universiteter, handelshøjskoler, handelsskoler, eksportskoler mv., som i forbindelse med deres studium indlærer pensum eller løser skriftlige og mundtlige opgaver, og 3) andre brugere, fx oversættere og lærebogsforfattere, informationsrådgivere, advokater og revisorer (side 3). Disse tre undergrupper virker umiddelbart som heterogene størrelser, da der er stor forskel grupperne imellem og inden for grupperne på den enkelte brugers faglige og sproglige kompetencer, og samtidig skal Business Leksikon tilsyneladende hjælpe med at løse både tekstafhængige og tekstuafhængige funktioner. Fælles for alle tre undergrupper er, at de kan bruge Business Leksikon til den tekstuafhængige funktion videntilegnelse, mens i hvert fald gruppe $2 \operatorname{og} 3$ også vil kunne bruge ordbogen til den tekstuafhængige funktion produktion af tekster på dansk, og de tekstafhængige funktioner oversættelse til engelsk, fransk og tysk, samt forståelse af danske fagtekster, jf. Bergenholtz/Kaufmann (1997, 98101).

\section{Ordbogens generelle opbygning}

Ordbogens overordnede struktur, rammestrukturen, er kompleks, og den består af et større antal byggedele, eller komponenter: et forord; en takkeliste indeholdende navne på virksomheder, organisationer og offentlige institutioner, som har bidraget til udarbejdelsen af ordbogen; en fortegnelse over anvendte forkortelser; en indholdsfortegnelse; en principal lemmaliste med udvalgte fagudtryk; en subsidiær lemmaliste med udvalgte faglige forkortelser; en indholdsfortegnelse til et appendiks om EU-ordninger; selve appendikset om EU-ordninger; samt plads til egne noter. Alt dette er fordelt på 720 sider. 


\section{Forteksten}

Fortekstens første komponent er forordet, som giver et udmærket indtryk af, hvad forfatterne ønsker at opnå med ordbogen, nemlig at den skal være et hjælpemiddel til videntilegnelse, forståelse af fagtekster, samt oversættelse og produktion af fagtekster (jf. ovenfor). Dette er helt i tråd med forordets genuine funktion, nemlig at leksikograferne her kan præsentere brugeren for ordbogens formål, funktion(er), brugernes forventede forudsætninger, samt ordbogens anvendelsespotentiale. Oplysningerne, som skal hjælpe brugeren med at opfylde en eller flere af ordbogens funktioner, er derfor afpasset disse: "Leksikonet forklarer på en systematisk måde en lang række udvalgte fagudtryk og begreber ..... i en klart og letforståeligt sprog med formuleringer, der gør værket let tilgængeligt for personer både med og uden egentlig handelsmæssig baggrund," som det udtrykkes i forordet (side 3). Der er ganske vist tale om en enkelt grammatisk fejl, men anvendelsen af den forkerte artikel i lige netop denne periode er ikke befordrende for brugerens tillid til, at ordbogen kan give den optimale eller nødvendige hjælp til løsning af relevante problemer. Den samme grammatisk ukorrekte formulering genfindes i ordbogens bagsidetekst, hvilket er uheldigt, da potentielle brugere ofte vil læse denne tekst inden de beslutter sig for, om de vil investere kr. 576 ekskl. moms i ordbogen.

Forordet indeholder også 2 linjer, der forklarer artiklernes opbygning, og dette er det nærmeste man kommer til en forklaring af, hvordan man bedst bruger ordbogen. Når man tager ordbogens intenderede brugergrupper, dens genuine funktioner og dens komplekse overordnede struktur i betragtning, er dette utilstrækkeligt. Der burde have været en selvstændig brugervejledning, som på en klar og præcis måde havde givet brugeren en indføring i ordbogens opbygning og indhold. Dette ville have hjulpet brugeren med at få det fulde udbytte af de oplysninger, ordbogen indeholder og samtidig have forklaret, hvordan brugeren hurtigst og nemmest finder de søgte oplysninger. Så ville brugeren have fået en forklaring på, hvorfor nogle termer i forklaringerne er kursiverede, hvorfor disse i nogle tilfælde virker som henvisninger til andre artikler og i andre ikke har denne funktion, hvilken rolle kapitlet om EU-ordninger har, hvorfor nogle definitioner fylder mindre end 1 linje (se fx artiklen gruppe), mens andre fylder op til 74 linjer (se fx artiklen koncernregnskab), og hvad pilen -> betyder, for bare at nævne nogle af de spørgsmål, det er overladt til brugeren selv at besvare.

Efter forordet følger en takkeliste med navnene på offentlige institutioner, erhvervsorganisationer og private virksomheder, som har været behjælpelige med "korrekturlæsning, formulering og oversættelse af udvalgte begreber" (side 4). Man må gå ud fra, at der ikke menes 'formulering af begreber', men at der derimod er tale om formulering af definitioner og forklaringer i artiklerne. En sådan takkeliste er ordbogens funktioner uvedkommende, men den giver i det 
mindste indtryk af, at der ligger en ikke ubetydelig faglig ekspertise bag arbejdet med ordbogen. Endvidere er dette et godt eksempel på, at fagleksikografer involverer den intenderede brugergruppe i den prækonceptuelle fase af et ordbogsprojekt, for på den måde at kunne udarbejde et leksikografisk værktøj, der er tilpasset brugerne og deres behov, se fx Tarp $(2000,198)$.

Listen over anvendte forkortelser er særdeles praktisk, da den forklarer betydningen af de forkortelser, brugeren vil støde på i ordbogen (side 5). Alle 32 forkortelser tilhører kategorien leksikografiske standardforkortelser, der også kendes fra almindelige faglige og ikke-faglige tekster, for eksempel alm. (= almindelig) og $t l f$. (= telefon). At der er tale om danske standardforkortelser er generelt en positiv ting, idet de fleste brugere vil kunne forstå fx artiklernes forklaringer uden de store problemer. Ordbogens forfattere har med andre ord tilpasset beskrivelsessproget efter brugernes forventede faglige og fagsproglige kompetence. Det kan dog undre, at både forkortelsen ang. (= angående) og vedr. (= vedrørende) anvendes, da udtrykkene er synonyme, men om ikke andet resulterer det $i$ en varieret sprogbrug. Tilsvarende gælder anvendelsen af forkortelsesparret $c f r$. (= konferer, sammenlign) og smgl. (= sammenlign), selvom den sidstnævnte ser underlig ud. Derimod er brugen af både forkortelsen $j f r$ og forkortelsen $j f$. et udtryk for inkonsekvent og sjusket sprogbrug, og her burde forfatterne have bestemt sig for kun at bruge én af forkortelserne. Denne inkonsekvens efterlader et indtryk af manglende overblik over eller kontrol med præsentationen af det faglige indhold.

Ved nærmere brug af ordbogen, støder man i forbindelse med de fremmedsproglige ækvivalenter på en forkortelse, der ikke er medtaget i forkortelseslisten og derfor heller ikke er forklaret, nemlig forkortelsen dän. (se fx artiklerne Danmarks vareindførsel og -udførsel og Danmedia). Det havde ikke været noget problem at medtage denne forkortelse i forkortelseslisten, og den burde have været medtaget, da den bidrager til ordbogens funktioner oversættelse og tekstproduktion. Samtidig er der tale om en forkortelse for det tyske adjektiv dänisch, hvilket man ikke kan forvente, at brugerne ved.

Umiddelbart efter listen over anvendte forkortelser findes indholdsfortegnelsen (side 6). Generelt er indholdsfortegnelsens formål at vise brugeren, hvad ordbogen i store træk indeholder, altså en oversigt i overskriftsform over ordbogens opbygning. Indholdsfortegnelsen i Business Leksikon er karakteriseret ved at være kort og uden henvisninger til sidetal. Samtidig er den mangelfuld, idet hverken takkelisten eller fortegnelsen over anvendte forkortelser er anført, selvom de er placeret mellem forordet og indholdsfortegnelsen. En indholdsfortegnelse er altid en god ting i en ordbog med en kompleks overordnet struktur, men det forudsætter, at den er fuldstændig. Det havde ikke krævet meget arbejde af leksikograferne at udarbejde en ordentlig indholdsfortegnelse med sidetal. 


\section{Lemmalisten og artiklerne}

Den principale lemmaliste, der er på 684 sider, indeholder ca. 5.000 fagudtryk og begreber. Der er således tale om næsten en fordobling af antallet af opslagsord i forhold til Dansk Eksportleksikon. Det altovervejende flertal er danske opslagsord, mens et mindretal udgøres af engelske, franske og tyske opslagsord, samt en enkelt svensk term (overeksekutor). Lemmalistens layout er forbedret betydeligt, sammenlignet med præsentationen af artiklerne i Dansk Eksportleksikon. Oprindeligt var teksten i lemmalisten skrevet i én spalte, mens man i Business Leksikon har to spalter på hver side, hvilket er en stor fordel, da det gør hele tekstbilledet mere læsevenligt. Samtidig er artiklernes tekst skrevet med en skriftstørrelse, der gør den let at læse, uden at man behøver anstrenge øjnene.

Langt størsteparten af opslagsordene er substantiver, fx data, lagerbeholdning og фsthandel, men der findes også adjektiver, fx bankerot og uopsigelig. Mange af substantiverne er flerordstermer, fx finansiel investering og regressiv $s k a t$, og ordbogen indeholder en del proprier i form af navne på danske, udenlandske og internationale organisationer og institutioner, fx Danmarks Nationalbank, Oberlandesgericht, EF-Domstolen og Verdenshandelsorganisationen.

Lemmalistens makrostruktur er alfabetisk og ordnet efter bogstav for bogstavmetoden (bortset fra lemmalistens første fire alfanumeriske lemmaer, der er ordnet i numerisk rækkefølge), men der er gået noget galt flere steder. For eksempel er lemmaet konkursbegæring placeret mellem lemmaerne konkurrerende devaluering og konkurrenceerhverv (der også begge er placeret forkert i den alfabetiske rækkefølge). Lemmaerne producentmarked, producentvare, producentvaremarked og product-pick-up er placeret mellem produktudvalg og produkt (i denne rækkefølge). Og efter lemmaet produkt, begynder man forfra i den alfabetiske rækkefølge med opslagsord, der begynder med produkt (fx produktansvar og produktcyklus), og som ikke var placeret korrekt første gang man fors $\varnothing$ gte at placere lemmaerne i den alfabetiske rækkefølge. Endvidere er ca. $20 \%$ af alle lemmaerne under bogstavet U placeret forkert, og lemmaerne forbrug, forbruger, forbrugervare, punktelasticitet, punktskat, slutseddel og slusepris er ligeledes placeret forkert. En ordentlig korrekturlæsning ville have løst disse for brugeren irriterende problemer.

Når man ser på lemmalisten, kan man ikke komme uden om lemmaselektionen. Der er medtaget nye termer som fx acquis communautaire og euro, men ifølge forordet, har man bevidst valgt ikke at lemmatisere begreber og fagudtryk fra den nye danske Årsregnskabslov, hvilket nedsætter ordbogens værdi noget, da Årsregnskabsloven er trådt i kraft. Det er som anmelder af ordbøger en taknemmelig opgave at kaste sig over lemmalisten og påpege manglende fagtermer og begreber, men et par smuttere fortjener omtale. Fra en systematisk, faglig syns- 
vinkel, kan det undre, at den eneste ordinære danske domstol, som ikke er lemmatiseret er Højesteret, at stavning er lemmatiseret, men ikke svarskrift, at saereje er lemmatiseret, men ikke falleseje eller formuefallesskab, at cand.merc. er lemmatiseret, men ikke cand.ling.merc., at korrespondent er lemmatiseret, men ikke $B A$ i erhvervssprog, at hvidbog er lemmatiseret, men ikke grønbog, at slutseddel er lemmatiseret, men ikke købskontrakt. Det er således tydeligt, at et ordentligt fagsystematisk princip for selektion af lemmaer ikke har været på plads fra ordbogsprojektets start, for den eneste årsag til, at de nævnte termer ikke er lemmatiseret i Business Leksikon er, at de heller ikke er lemmatiseret $\mathrm{i}$ Dansk Eksportleksikon. Da Business Leksikon er en videreudvikling af Dansk Eksportleksikon, må man som en selvfølge kunne gå ud fra, at leksikograferne har fundet og afhjulpet de mangler, der var, men det er øjensynligt ikke sket. En bedre strukturering og konsekvent styring af ordbogsprojektet ville have resulteret i en mere optimal lemmaselektion, til glæde for ordbogens brugere.

Til stor hjælp for brugerne, er artiklerne opbygget efter et bestemt artikelskema, der er fulgt konsekvent, således at man opnår en ensartet præsentation af artiklernes oplysninger. Alle artiklerne indledes af det danske opslagsord (lemma), og derefter følger oversættelse af lemmaet til engelsk, fransk og tysk (ækvivalenterne). Sidst i artiklen, finder man en dansk definition og/eller forklaring af lemmaet, samt evt. henvisninger til andre artikler. Henvisningsartiklerne indeholder ingen definition, men i stedet en henvisning til en anden artikel, i hvilken man får en definition af henvisningsartiklens lemma. Dette er i overensstemmelse med almindelig anerkendt leksikografisk praksis.

\section{Tekstproduktion og oversættelse}

Tekstproduktion er en af ordbogens genuine funktioner, så det kan undre, at alle lemmaer er skrevet med versaler (jf. eksemplerne nedenfor). Dette er uhensigtsmæssigt, da ordbogen dermed bliver næsten uanvendelig til produktion på og oversættelse til dansk, for man kan ikke se, hvordan opslagsordene skrives korrekt, hvis man er i tvivl om brugen af store begyndelsesbogstaver i enkeltog flerordstermer. Det havde været hensigtsmæssigt, hvis alle appellativer havde været skrevet med små bogstaver og alle proprier skrevet med stort begyndelsesbogstav. Havde dette princip været fulgt, ville brugeren af Business Leksikon have vidst, at den korrekte stavemåde er Europa-Parlamentet og for eksempel ikke Europa-parlamentet, hvilket ville have været en naturlig slutning, når man ved, at den korrekte stavemåde er Amsterdam-traktaten. Ordbogens værdi som hjælpemiddel til produktion på og oversættelse til dansk ville have været betydelig større, end det nu er tilfældet, hvis lemmaerne havde været præsenteret i henhold til almindeligt gældende danske retskrivningsregler. 
I forbindelse med ækvivalenterne, findes enkelte unøjagtigheder. Den engelske ækvivalent til lemmaet reklamekodeks er code of fair practice, hvilket kan anvendes om enhver branche. Hvorfor ikke tage udgangspunkt i ICC's international code of advertising practice, der jo netop er en reklamekodeks? Tilsvarende oversætter ordbogen lemmaet ejendomsforbehold til det engelske conditional sale, der betyder ' $k \varnothing \mathrm{b}$ med ejendomsforbehold', mens ejendomsforbehold på engelsk hedder retention of title. Undertiden skyldes unøjagtigheden, at opslagsordet, ækvivalenterne og forklaringen ikke passer sammen. Dette kan ses ved lemmaet køre- og hviletidsbestemmelser, der ikke på noget af sprogene er oversat nøjagtigt, men derimod med titlen på den aftale, der inden for EU regulerer arbejde med international vejtransport, og som er det gennemgående tema i forklaringen, på tysk Übereinkommen über die Arbeit des im internationalen Straßenverkehr beschäftigten Personals. En nøjagtig oversættelse af lemmaet er legislation on driving and rest periods, legislation relative au temps de conduite et de repos, og Lenk- und Ruhezeitvorschriften.

En omtale af Business Leksikon i Århus Stiftstidende indledes med spørgsmålet "Er 'stormagasin' og 'storcenter' det samme ord på fransk?", og teksten fortsætter "Svaret er enkelt. Man slår op i Business Leksikon", Krøger (2001). Når man læser de to artikler i ordbogen, får man det indtryk, at det er helt bevidst, der spørges om fransk og ikke engelsk eller tysk, for det er kun den franske oversættelse af lemmaet storcenter, centre commercial, der er korrekt. Storcenter oversætter ordbogen til det engelske department store og de tyske termer Kaufhaus og Warenhaus, hvilket er forkert, da alle tre ækvivalenter betyder stormagasin. Et storcenter hedder på engelsk (community) shopping centre eller shopping mall, og på tysk Einkaufszentrum.

Dette er ikke det eneste eksempel på forkerte ækvivalenter i Business Leksikon. Da forfatterne i forordet, side 3, opfordrer brugerne til at komme med præciseringer af oversættelser (endnu et glimrende eksempel på brugerinvolvering, men denne gang i den post-konceptuelle fase), følger nedenfor nogle udvalgte eksempler på ukorrekte ækvivalenter. Stævning hedder ikke writ of summons, men claim form (UK) og complaint (US). Investeringsforening hedder ikke investment group eller club d'investissement, men unit trust (UK), (openend) mutual fund (US) samt société d'investissement à capital variable (sicav). Retspraksis hedder ikke legal usage eller Rechtspraxis, men case law og Gerichtspraxis. Retssædvane hedder ikke case law, men legal custom. Skik hedder ikke case law, men (trade) custom. Konkurrenceforbud hedder ikke closed shop agreement, men restrictive covenant eller non-competition clause. Fællesflydning hedder ikke floating currencies, men joint floating. Mønsterbeskyttelse hedder ikke pattern protection, men design protection. Handelsagent hedder ikke agent eller sales representative, men commercial agent. Eneforhandler hedder ikke 


\section{4}

sole eller exclusive agent, men sole eller exclusive distributor. Retsvalgsklausul hedder ikke venue clause, men choice-of-law clause. Emission af værdipapirer hedder ikke emission på engelsk, men issue. Distributørmærke hedder ikke produit drapeau, men produit de distributeur. High Court hedder ikke cour suprême eller oberstes Gericht, men svarer til hhv. tribunal de grande instance og Landgericht. Osv.

Grunden til, at Business Leksikon, i modsætning til Dansk Eksportleksikon, indeholder engelske, franske og tyske oversættelser af opslagsordene er, ifølge en af ordbogens forfattere, bl.a., "at især mange ingeniører, der arbejder internationalt, har store sproglige problemer, når de skal udtrykke sig på skrift", og "Danskerne tror ofte, at de taler og skriver væsentligt bedre på fremmedsprog, end de i virkeligheden gør”, Krøger (2001). Som det fremgår ovenfor, kan man finde unøjagtige og ukorrekte ækvivalenter i Business Leksikon, men det er vigtigt at fastslå, at der også kræves andre oplysninger om ækvivalenterne, hvis ordbogen skal kunne opfylde funktionerne oversættelse til og produktion på et fremmedsprog. Især når man tager ovenstående to citater i betragtning. Business Leksikon indeholder fx ingen sproglige angivelser vedrørende ækvivalenterne til fransk og tysk. For at kunne opfylde disse funktioner, er det i hvert fald nødvendigt med ordklasseangivelser, da man ikke kan forvente, at ordbogens intenderede brugergruppe (fx danske ingeniører) er kyndig i fransk og tysk fagsprog.

For at producere korrekte tekster på og lave korrekte oversættelser til et fremmedsprog, kan det være af største vigtighed, at man benytter sig af den korrekte fagterminologi. For at hjælpe brugerne kan man i ordbogen gøre brug af diasystematiske markeringer, som fx angiver en ækvivalents geografiske tilhørsforhold (diatopisk markering) eller en ækvivalents faglige tilhørsforhold (diateknisk markering). Det er fx ikke ligegyldigt, om man anvender et britisk eller amerikansk fagudtryk eller begreb, og for at hjælpe brugerne findes diatopiske markeringer i Business Leksikon, som i følgende artikel:

\section{FORBRUGSAFGIFT}

value-added tax (UK); sales tax (US)

impôt sur la consommation; droit d'accise

Verbrauchssteuer

Skat på køb af varer og tjenesteydelser. For-

brugsafgifterne er indregnet $i$ varepriserne

og derved endelig betalt af forbrugerne. Forbrugerafgift, der omfatter punktafgift og omsætningsafgift, udgør en betydelig andel af statens indtægter. 
De diatopiske markeringer, der benyttes er (UK), (US) og (EU), og de burde kunne forstås af brugeren, selv om de ikke er forklaret i listen over anvendte forkortelser. Til trods for, at diatopiske markeringer er vigtige ved oversættelse til et fremmedsprog, bruges de kun ved engelske ækvivalenter og altså ikke ved de franske og tyske. Ca. $1 \%$ af de 5000 artikler indeholder diatopiske markeringer.

Diatekniske markeringer bruges også i Business Leksikon til at præcisere betydningen af et lemma og de dertil hørende ækvivalenter, fx:

\section{UDBETALING}

1) one-time licence fee; 2) down-payment

1) paiement; 2) acompte

1) Zahlung; 2) Anzahlung

Begrebet bruges primært i to sammenhænge:

1) Engangsafgift ved licensaftale; 2) Første betaling ved afbetalingsk $\phi b$ eller køb hvor resten af købesummen forfalder på eller senere end leveringstidspunktet.

Det fremgår af denne artikel, at lemmaet har to betydninger og hvilke ækvivalenter, der hører til hhv. den første og den anden betydning. Anvendelsen af arabertal er både pladsbesparende og entydig.

Samlet er det kun ca. 5\% af de 5000 artikler, der indeholder diasystematiske markeringer til ækvivalenterne (se også artiklerne advokat, anlæg, branche, nota og valorisation). Alt for mange artikler mangler oplysninger om betydningen og brugen af de anførte ækvivalenter. I artiklen konkurs er den eneste engelske ækvivalent bankruptcy, som på amerikansk omfatter personlig konkurs og selskabskonkurs, mens bankruptcy i England kun anvendes om personlig konkurs. Lemmaet betalingsstandsning oversætter ordbogen til application for an administration order, hvilket er et begreb, der kun eksisterer i engelsk ret, og det er vel de færreste, som har brug for at fortælle, at en dansk virksomhed har anmodet en engelsk domstol om tilladelse til at gå i betalingsstandsning i henhold til specielle engelske regler, der kun finder anvendelse på aktie- og anpartselskaber. Med hensyn til de engelske ækvivalenter til lemmaet selskabsskat, burde der have været en diatopisk markering, der anfører, at corporation tax er det korrekte britiske og company tax det korrekte amerikanske fagudtryk. I artiklen lejekontrakt burde det i form af en diateknisk markering have været anført, at den engelske ækvivalent tenancy agreement kun kan anvendes om fast ejendom, og at ækvivalenten hire contract kun kan anvendes om løsøre. I artiklen aftale burde det have været præciseret, at de anførte franske ækvivalenter, convention og accord, bruges i betydningen international konvention hhv. almindelig aftale, der kan være enten retligt bindende eller uforpligtende (sammenlign med artiklen agentaftale, hvor den korrekte franske ækvivalent, contrat d'agent, er 
anført). Afslutningsvis skal det nævnes, at artiklerne sekundær information og tidsserie mangler engelske ækvivalenter og, at artiklen balance mangler franske ækvivalenter. Det må efter en nærmere gennemgang af Business Leksikon konstateres, at ordbogen lader meget tilbage at ønske som et værktøj til produktion af fagtekster på og oversættelse af fagtekster til engelsk, fransk og tysk.

\section{Videntilegnelse og tekstforståelse}

I forbindelse med funktionerne videntilegnelse og tekstforståelse, er det af stor værdi, at Business Leksikon forklarer fagudtryk og begreber på en systematisk måde. Denne systematiske fremstilling er vigtig for ordbogens brugere, således at de kan danne sig et overblik over, hvor i den faglige systematik et konkret fagudtryk eller begreb befinder sig. Forklaringerne og definitionerne i artiklerne er udformet på en sådan måde, at de tager højde for den relevante fagsystematik således, som det fremgår af følgende eksempel:

\section{VARER UNDER FREMSTILLING \\ $[\ldots .$. \\ Arabertalspost under romertalsposten vare- beholdninger. Posten dækker over egenfrem- stillede halvfabrikata for egen regning. An- dre egenfremstillede halvfabrikata opføres under igangværende arbejder for fremmed regning.}

Definitionen er kort, klar og letforståelig og viser hvorledes varer under fremstilling adskiller sig fra igangværende arbejder for fremmed regning. Helt optimalt ville det have været, hvis det eksplicit havde fremgået af artiklen, at begrebet hører til faget regnskabsvæsen, og at forklaringen kun vedrører denne betydning, fx ved hjælp af en diateknisk markering. Andre eksempler på gode, systematiske fremstillinger er artiklerne behov, markedsføringsplan, transportdokument og valutaarbitrage.

Business Leksikon gør også brug af en anden fremgangsmåde til belysning af den faglige systematik, nemlig oversigtsartikler. Dette er en særdeles brugervenlig og fagligt god måde at præsentere systematiske sammenhænge på, og disse artikler fungerer bedst, når de indeholder oplysninger om relationerne mellem et overbegreb og de dertil hørende underbegreber, se fx Bergenholtz/ Tarp/Wiegand (1999, 1782-1783). Et godt eksempel er artiklen eksportmarkedsvalg, som giver en generel beskrivelse af dette begreb gennem en forklaring af de to former passivt og aktivt markedsvalg. Derefter gives en beskrivelse af de to underformer for aktivt markedsvalg, dvs. den ekspansive og den kontraktive markedsprioriteringsmetode. Man får på denne måde en samlet systematisk oversigt over relaterede fagtermer og begreber. Artiklerne aktivt markedsvalg, pas- 
sivt markedsvalg, ekspansiv markedsprioriteringsmetode og kontraktiv markedsprioriteringsmetode er alle realiseret som henvisningsartikler, der kun indeholder de relevante fremmedsproglige ækvivalenter og en henvisning til oversigtsartiklen, således at der spares plads ved kun at skrive definition og forklaring én gang.

Det er dog ikke lykkedes at være lige så konsekvent og systematisk i behandlingen af alle fagudtryk. Havde man konsekvent fulgt princippet om at forklare opslagsordene på en systematisk måde, ville artiklen integration have forklaret brugeren, at man skelner mellem to former, vertikal og horisontal integration, og artiklen vertikal integration ville have forklaret brugeren, at man skelner mellem to former, baglæns og forlæns integration. Dette ville have givet et indtryk af den faglige systematik i modsætning til forklaringerne i Business Leksikon, hvor artiklerne hverken henviser til hinanden eller på anden måde viser den faglige sammenhæng mellem begreberne, noget som ellers er vigtigt for ordbogens brugergruppe ved videntilegnelse og tekstforståelse. Den manglende systematik i disse artikler er muligvis også grunden til, at ordbogen oversætter lemmaet baglæns integration forkert på to sprog, nemlig engelsk vertical integration og fransk intégration veticale, kun den tyske ækvivalent Rückwärtsintegration er korrekt. Den korrekte engelske term er backward integration og den franske er intégration amont. Helt galt er det gået $\mathrm{i}$ artiklen forlæns integration, som ordbogen oversætter til horizontal integration og concentration horizontale, og igen er kun den tyske ækvivalent Vorwärtsintegration korrekt. Den korrekte engelske term er forward integration og den franske intégration aval.

Hvis forklaringerne til lemmaerne standsningsret og tilbageholdsret havde været klarere og fx indeholdt en oplysning om, at tilbageholdsret kun kan udøves så længe sælgeren har de solgte varer i sin besiddelse, hvorimod standsningsret kun kan udøves af sælgeren, når de solgte varer er afsendt, men endnu ikke overgivet til køberen, så havde man opnået en bedre fremstilling af den relevante fagsystematik og (forhåbentligt) opnået, at den engelske ækvivalent til standsningsret havde været korrekt, nemlig right of stoppage in transit, i stedet for den ukorrekte term right of retention, som er den korrekte engelske term for tilbageholdsret.

Det generelle indtryk af de faglige forklaringer er, at de i de fleste tilfælde på fagligt og sprogligt velovervejet vis forklarer betydningen af de lemmatiserede fagudtryk og begreber. Ved en stikprøve af artiklerne er der kun fundet én forklaring, som ikke er fagligt korrekt, nemlig i artiklen public limited company: 


\section{PUBLIC LIMITED COMPANY}

Public Limited Company; -> PLC

société annonyme; -> S.A.

Public Limited Company

Engelsk betegnelse for et børsnoteret sel-

skab.

Den danske forklaring er ikke korrekt, idet et engelsk public limited company, i lighed med et dansk aktieselskab, har mulighed for at sælge sine aktier på en fondsbørs, men det er langt fra alle public limited companies, der er børsnoterede. Endvidere skrives public limited company oftest uden brug af versaler i engelske tekster. Den korrekte engelske betegnelse for et børsnoteret selskab er listed eller quoted company. Med ovenstående forbehold, udgør Business Leksikon et udmærket værktøj til opfyldelse af funktionerne videntilegnelse og forståelse af fagtekster.

\section{Bagtekster}

Den subsidiære lemmaliste indeholder på 7 sider 181 forkortelser, primært danske og engelske, i alfabetisk rækkefølge. Man må gå ud fra, at disse forkortelser er medtaget fordi brugerne efter al sandsynlighed vil støde på dem i forbindelse med videntilegnelse, tekstforståelse, tekstproduktion og oversættelse, altså at de er fagligt relevante. Dette bliver også bekræftet ved en hurtig gennemgang af forkortelserne under bogstavet $\mathrm{A}$, som fx $A / S$ (= aktieselskab), $A f D B$ (= Den Afrikanske Udviklingsbank) og AVS (= AVS-landene). Det er dog svært at se den specielt faglige relevans af forkortelser som $D O$ (= ditto) og $N B$ (= nota bene). Alle artiklerne er bygget op efter den samme skabelon: et lemma efterfulgt af det uforkortede fagudtryk. Sidstnævnte fungerer samtidig som en henvisning til det uforkortede lemma i den principale lemmaliste, hvor man finder oversættelser og forklaring. De uforkortede fagudtryk er alle skrevet med versaler, så heller ikke her får brugeren hjælp til retskrivningen.

Efter den subsidiære lemmaliste følger en indholdsfortegnelse til den efterfølgende tekst, som omhandler EU-ordninger. I modsætning til den første indholdsfortegnelse, er denne fuldstændig og har henvisninger til siderne 2-16. Desværre er de sider der henvises til nummereret 700-714, altså en delvis ubrugelig indholdsfortegnelse. Det fremgår intet sted i Business Leksikon, hvad den 15 sider lange tekst om EU-ordninger skal bruges til, men i omtalen i Århus Stiftstidende kan man læse, at det drejer sig om EU-støtteordninger, se Krøger (2001). Selv om forfatterne måtte mene, at anvendelsesmulighederne af teksten om EU-ordninger er legio, burde de for at hjælpe brugeren eksplicit have anført, hvad teksten (især) kan buges til, og hvordan den understøtter ordbogens funktioner, enten som indledning til teksten eller i en brugervejledning. 
Det fremgår heller ikke, hvilken systematik, der ligger bag præsentationen af ordningerne, men teksten er opdelt i følgende hovedgrupper: 1) Alment merkantile forhold, 2) EU's konkurrenceregler, 3) EU-programmer, lån og støtteordninger, 4) EU's landbrugspolitik og markedsordninger, og 5) retsakter. Der er ingen tvivl om, at brugerne her vil kunne finde interessante og nyttige oplysninger og henvisninger, bl.a. vedrørende støtte til udviklingslande, transnationalt forskningssamarbejde og erhvervsuddannelser. Som noget nyt og særdeles nyttigt, finder man Internet-adresser på en mængde institutioner og støtteordninger således, at man har mulighed for at finde yderligere oplysninger om disse. Selv om der er tale om en kort gennemgang, er der ikke tvivl om, at oplysningerne bidrager til videntilegnelse og forståelse af fagtekster. Helt optimalt ville det have været med eksplicitte henvisninger mellem artiklerne i lemmalisten og teksten om EU-ordninger, så brugeren fx kunne blive henvist fra en artikel omhandlende en EU-institution til det relevante sted i bagteksten, hvor institutionens web-adresse er anført.

Ordbogen afsluttes med 6 linjerede sider a 26 linjer, hvor brugeren kan indføre sine egne notater.

\section{Konklusion}

Sammenfattende kan det konstateres, at Business Leksikon lider af en grundlæggende mangel på acceptabelt og godt leksikografisk arbejde, både i den forberedende og den udførende fase, hvilket spiller negativt ind på det færdige produkt. En systematisk og kontrolleret arbejdsplan ville have resulteret $i$ bedre og indbyrdes sammenhængende definitioner og forklaringer, samt en optimal selektion af opslagsord. Generelt er Business Leksikon egnet for brugere, der ønsker at tilegne sig viden om de udvalgte fagudtryk og begreber, og som ønsker at forstå fagtekster, hvori disse forekommer. Business Leksikon er generelt uegnet for brugere, som $\emptyset$ nsker at producere tekster på og oversætte tekster til engelsk, fransk og tysk, da ordbogen fuldstændig mangler grammatiske oplysninger til ækvivalenterne, indeholder for mange unøjagtige og ukorrekte ækvivalenter, og har en katastrofal mangel på diasystematiske markeringer. Der findes allerede flere bilingvale ordbøger på markedet, som er væsentligt bedre til produktion af fagtekster på og oversættelse af fagtekster til engelsk, fransk og tysk.

\section{Bibliografi}

Bergenholtz, Henning \& Kaufmann, Uwe (1997). Terminography and Lexicography. A Critical Survey of Dictionaries from a Single Specialised Field. In Hermes 18. 1997, 91-125. 
Bergenholtz, Henning, Tarp, Sven \& Wiegand, Herbert Ernst. Datendistributionsstrukturen (1999). Makro- und Mikrostrukturen in neueren Fachwörterbüchern. In L. Hoffmann, H. Kalverkämper, H. E. Wiegand et al. (Hrsg.): Fachsprachen. Ein internationales Handbuch zur Fachsprachenforschung und Terminologiewissenschaft. Teilband 2. Berlin/New York: Walter de Gruyter, 1762-1832.

Kezunovic, Bozidar \& Lynderup, Jens Peder (1993). Dansk Eksportleksikon. Åbyhøj: BK SERVICE.

Krøger, Alice (2001). Leksikon bryder grænser for forretningsfolk. Århus Stiftstidende Netavis, 24. december 2001.

Nielsen, Sandro (1990). Contrastive Description of Dictionaries Covering LSP Communication. In Fachsprache/International Journal of LSP 3-4, 1990. 129-136.

Tarp, Sven (2000). Theoretical Challenges to Practical Specialised Lexicography. In Offprint from Lexikos 10, a keynote address at the Fifth International Conference of the African Association for Lexicography. Afrilex-reeks/series 10:2000. 189-208. 